\title{
PERAN ISLAMIC CORPORATE SOCIAL RESPONSIBILITY DALAM MEMODERASI PENGARUH ZAKAT TERHADAP KINERJA BANK UMUM SYARIAH
}

\author{
Sartini Wardiwiyono \&Arty Fitria Jayanti \\ Universitas Ahmad Dahlan \\ Jl. Kapas 9, Semaki, Umbulharjo, Yogyakarta 55166 \\ Email: sartini.w@act.uad.ac.id; artyjayanti@gmail.com
}

\begin{abstract}
The aim of this study is to investigate the role of Islamic Corporate Social Responsibility in moderating the effect of zakat on Islamic commercial banks' financial performance. Out of 13 Islamic commercial bank listed by Otoritas Jasa Keuangan from 2012 to 2017, there were only five banks reporting Statement of Zakat Fund Sources and Disbursements. Hence, the final samples of this study consist of 30 observation data. Secondary data collected from 30 annual reports were gathered through documentation. This study utilizes moderated regression analysis to test three research hypotheses. The results shows several findings. Firstly, the amount of corporate zakat being reported in the Statement of Zakat Fund Sources and Disbursements has positive impact on Islamic banks' financial performance. Secondly, Islamic CSR as measured by Islamic reporting index developed by Belal et al. (2015) has negative impact on Islamic Banks' financial performance. Thirdly, the role of Islamic CSR in moderating the effect of zakat on financial performance was confirmed.
\end{abstract}

Keywords: Islamic CSR; Zakat; Islamic Banks; Financial Performance

\section{ABSTRAK}

Tujuan dari penelitian ini adalah untuk mengetahui peran Islamic Corporate Social Responsibility dalam memoderasi pengaruh zakat terhadap kinerja keuangan bank umum syariah. Dari 13 bank umum syariah yang terdaftar oleh Otoritas Jasa Keuangan dari tahun 2012 hingga 2017, hanya ada lima bank yang melaporkan Pernyataan Sumber dan Pencairan Dana Zakat. Sehingga sampel akhir dari penelitian ini terdiri dari 30 data observasi. Data sekunder yang dikumpulkan dari 30 laporan tahunan dikumpulkan melalui dokumentasi. Penelitian ini menggunakan analisis regresi yang dimoderasi untuk menguji tiga hipotesis penelitian. Hasilnya menunjukkan beberapa temuan. Pertama, jumlah zakat perusahaan yang dilaporkan dalam Laporan Sumber dan Pencairan Dana Zakat berdampak positif terhadap kinerja keuangan bank syariah. Kedua, CSR Islami yang diukur dengan indeks pelaporan Islam yang dikembangkan oleh Belal et al. (2015) berdampak negatif terhadap kinerja keuangan Bank Islam. Ketiga, peran CSR Islam dalam memoderasi pengaruh zakat terhadap kinerja keuangan dikonfirmasi.

Kata kunci: CSR Islami; Zakat; Bank Islam; Kinerja keuangan 


\section{PENDAHULUAN}

Bank syariah atau bank Islam merupakan bank yang implementasinya tidak berdasarkan bunga. Bank yang juga disebut sebagai bank tanpa bunga ini merupakan lembaga keuangan perbankan yang operasional serta produknya dikembangkan berlandaskan Al-Qur'an dan Hadist Nabi SAW (Muhammad, 2005:13). Perkembangan bank umum syariah di Indonesia ditandai dengan berdirinya Bank Muamalat Indonesia pada tahun 1992 yang menjadi salah satu perbankan yang beroperasi dengan menggunakan prinsip syariah (Khabibah dan Siti, 2013).

Berdasarkan data statistic, hingga tahun 2018 terdapat 13 Bank Umum Syariah (BUS), 20 Unit Usaha Syariah (UUS) dan 168 Bank Pembiayaan Rakyat Syariah (BPRS) (OJK, 2018). Semakin meningkatnya jumlah bank syariah yang beroperasi di Indonesia akan turut meningkatkan jumlah wajib zakat perusahaan (Firmansyah dan Aam, 2013).

Zakat merupakan salah satu instrumen yang berpotensi memberikan kemaslahatan bagi masyarakat. Berdasarkan hasil survei Baznas dan ADB (Asian Development Bank), potensi zakat di Indonesia sudah mencapai 217 triliun rupiah (Republika, 2018). Dari besarnya potensi zakat tersebut, bank syariah yang dikenal lekat dengan nilai keislamannya sudah sepatutnya mengimplementasikan dan menjalankan kewajibannya yakni mengeluarkan zakat secara konsisten. Pengeluaran zakat yang dilakukan secara konsisten oleh bank syariah akan menjadi perantara dalam memberikan sinyal positif terhadap masyarakat. Harapannya, hal tersebut akan memberikan dampak terhadap reputasi dan kinerja bank syariah itu sendiri.

Zakat yang berasal dari Islam dan Corporate Social Responsibility (untuk seterusnya ditulis CSR) yang berasal dari konsep Barat merupakan dua hal yang saling berkaitan erat. Melalui pembayaran zakat atau penerapan CSR, bank syariah akan dapat memberi manfaat langsung kepada lingkungan dan masyarakat yang berada di sekitar perusahaan (Rika, 2016). Berdasarkan teori legitimasi, jika bank syariah melaksanakan kewajibannya membayar zakat dan didistribusikan kepada masyarakat di sekitar bank, maka keberadaan bank di mata masyarakat akan semakin kuat. Dengan legitimasi tersebut, bank syariah akan dapat meningkatkan kinerjanya karena kepercayaan masyarakat yang meningkat akan menjamin keberlangsungan hidup bank serta mampu meningkatkan kepercayaan investor (Arshah et al.) Penerapan CSR oleh bank syariah pun akan memberikan dampak yang sama bagi bank syariah. Sebagai institusi yang beroperasi berdasar syariah Islam, CSR yang diterapkan oleh bank syariah lebih cocok mengacu pada konsep Islamic Corporate Social Responsibility (ICSR). Menurut Khurshid et al. ICSR merupakan tanggung jawab sosial perusahaan yang berlandaskan prinsip-prinsip syariah (Sidik dan Reksino, 2016).

Meskipun zakat dan ICSR merupakan dua konsep yang memiliki tujuan dan karakteristik yang hampir sama, dari perspektif Islam, zakat biasanya dipandang lebih penting dari ICSR. Zakat merupakan bagian dari lima rukun Islam yang wajib dijalankan oleh semua Islam yang mampu. 
Bank syariah yang merupakan badan hukum syariah terdiri dari sekumpulan orang yang berkomitmen untuk menjalankan operasi bank sesuai dengan syariah Isla. Sekumpulan orang tersebut, jika beragama Islam dan sudah memenuhi syarat memiliki kewajiban membayar zakat. Oleh karena itu, jika bank syariah membayar zakat atas keuntungan yang diperolehnya, maka berarti bank tersebut telah mewakili semua pihak dalam bank syariah menjalankan kewajibannya.

Riset-riset empiris tentang hubungan zakat, ICSR dan kinerja keuangan bank syariah masih terbatas jumlahnya dan dilakukan secara parsial. Hasil riset terdahulu tentang pengaruh zakat terhadap kinerja bank syariah menunjukkan bahwa zakat berpengaruh terhadap kinerja (Ramadhani, 2016; Sidik dan Reskino, 2016; Amirah dan Teguh, 2013). Berkaitan dengan pengaruh ICSR terhadap kinerja bank syariah, Arifin dan Eke (2013) tidak berhasil membuktikan hubungan tersebut pada sampel bank syariah tahun 2011-2013. Temuan Arifin dan Eke (2013) ini bertentangan dengan teori legitimasi. Dari perspektif teori legitimasi, perusahaan termasuk bank syariah yang melakukan CSR/ICSR akan memperoleh legitimasi dari masyarakat untuk menjaga keberlangsungan usahanya. Hal tersebut akan dapat menaikkan kepercayaan masyarakat maupun investor sehingga perusahaan/bank tersebut akan dapat berkinerjalebih baik.

Merujuk pada temuan teori legitimasi dan hasil riset terdahulu, penelitian ini ditujukan untuk menguji kembali hubungan antara zakat, ICSR dan kinerja bank syariah. Berbeda dengan penelitian terdahulu, penelitian ini menggabungkan zakat dan ICSR dalam satu model. Selain itu, penelitian ini menggunakan data yang lebih baru. Dengan mempertimbangkan hasil penelitian Arifin dan Eke (2013), variabel ICSR dalam penelitian ini tidak hanya diperlakukan sebagai variabel independen namun juga diperlakukan sebagai variabel moderasi. Oleh karena itu, secara spesifik, penelitian ini ditujukan untuk menjawab tiga pertanyaan penelitian. Ketiga pertanyaan tersebut adalah: 1). Apakah zakat berpengaruh terhadap kinerja bank syariah? 2). Apakah ICSR berpengaruh terhadap kinerja bank syariah? 3). Apakah ICSR memoderasi pengaruh zakat terhadap kinerja bank syariah?

\section{TELAAH TEORITIS DAN PENGEMBANGAN HIPOTESIS}

\subsection{KINERJA KEUANGAN BANK UMUM SYARIAH}

Bank umum syariah (BUS) merupakan bank syariah yang dalam kegiatannya dapat memberikan jasa dalam lalu lintas pembayaran. Selain menjadi lembaga perantara keuangan yang melakukan aktivitas pengumpulan dan penyaluran dana dari masyarakat dan untuk masyarakat, BUS juga dapat menerbitkan cek, bilyet giro dan alat pembayaran non tunai lainnya. Undangundang Nomor 21 Tahun 2008 tentang perbankan syariah menyatakan bahwa bentuk hukum yang diperkenankan untuk BUS adalah Perseroan Terbatas.

BUS secara lebih khusus diatur dalam peraturan pelaksanan UU Perbankan syariah yaitu Peraturan BI No. 11/3/PBI/2009 tentang Bank 
Umum Syariah. PBI tersebut diundangkan pada tanggal 29 Januari 2009. Pasal 2 dari peraturan tersebut menegaskan bahwa bentuk badan hukum BUS adalah perseroan terbatas. Berkaitan dengan modal disetor, pasal 5 menyebutkan bahwa modal disetor untuk mendirikan bank ditetapkan paling kurang sebesar Rp. 1.000.000.000.000 (satu triliun rupiah).

Seperti halnya perusahaan yang berorientasi bisnis, BUS diharapkan selalu dapat menghasilkan kinerja yang baik. Kinerja merupakan suatu cara untuk mengukur hasil yang telah dicapai oleh suatu program atau kegiatan dalam mengimplementasikan tujuan suatu organisasi. Dalam mencapai suatu tujuan perusahaan dibutuhkan kinerja yang maksimal untuk mengetahui keberhasilan yang telah dilakukan oleh suatu perusahaan (Ramadhani, 2016).

Metode pengukuran kinerja BUS telah mengalami beberapa perubahan mulai dari konsep CAMEL modified hingga metode terakhir yaitu Risk Based Bank Rating (RBBR). Bahkan, agar lebih mencerminkan tujuan sesungguhnya pendirian bank syariah menurut Islam telah muncul metode pengukuran kinerja BUS dengan pendekatan maqasid asy-syariah (Wardiwiyono, 2020). Namun demikian, khusus untuk tujuan riset-riset tentang hubungan kinerja BUS dengan variabel-variabel atau faktor-faktor lain, pengukuran kinerja BUS biasa dilakukan dengan menggunakan metoda yang lebih sederhana seperti rasio keuangan. Secara lebih spesifik, rasio keuangan yang biasa dipakai untuk tujuan penelitian-peneliti seperti itu. adalah profitabilitas. Dalam analisis laporan keuangan, profitabilitas bisa diproksikan dengan rasio seperti ROE, ROA, EAT dan yang lainnya.

\subsection{ZAKAT PERUSAHAAN}

Dari segi bahasa, zakat memilki kata dasar "zaka" yang berarti berkah, tumbuh, suci, bersih dan baik. Secara terminologi, zakat berarti aktivitas memberikan harta tertentu yang diwajibkan Allah SWT dalam jumlah dan perhitungan tertentu untuk diserahkan kepada orang-orang yang berhak (Nurhayati dan Wasilah, 2014: 282). Pengelolaan zakat di Indonesia diatur dalam UU. No.23 tahun 2011 tentang pengelolaan zakat. Pasal 1 ayat 2 dari UU tersebut menyatakan bahwa zakat adalah harta atau kekayaan yang dikeluarkan secara wajib oleh seorang muslim diberikan kepada yang berhak menerima zakat.

Sebagai sebuah aktivitas ibadah yang diperintahkan oleh Allah SWT, perintah zakat disertai pedoman yang jelas berdasar Al Qur'an dan Hadith Rosulullah SAW (Qordhowy, 2000). Pedoman tersebut mencakup pedoman tentang harta yang harus dizakatkan, batas harta yang dizakatkan, cara menghitung zakat dan yang berhak menerima zakat telah (Nurhayati dan Wasilah, 2014: 282). Karena zakat juga berkaitan dengan masalah ekonomi yang selalu berkembang mengikuti zaman, permasalahan-permasalahan tentang zakat yang baru muncul dapat diselesaikan berdasarkan fatwa hasil ijtihad dari para ulama fiqih dan ahli ekonomi Islam. Salah satu contoh permasalahan tentang zakat yang relatif baru adalah tentang zakat perusahaan. 
Dalam Muktamar Internasional Pertama tentang Zakat di Kuwait pada bulan Mei 1984, para ulama peserta muktamar bersepakat menganalogikan zakat perusahaan dengan zakat perdagangan. Ditinjau dari aspek legal dan ekonomi, kegiatan perusahaan pada umumnya berkaitan dengan kegiatan trading atau perdagangan. Karena mengambil istinbath dari zakat perdagangan, maka pola pembayaran dan perhitungan zakat perusahaan seacara umum adalah sama dengan pola pembayaran dan penghitungan zakat perdagangan (Hafidhuddin, 2002: 101). Terdapat beberapa syarat yang harus dipenuhi agar zakat perusahaan dapat dibayarkan. Syarat-syarat tersebut adalah kepemilikan perusahaan dikendalikan oleh muslim/muslimin dan usaha yang dijalankan harus halal. Selain itu, asset perusahaan harus dapat diukur, berkembang, dan minimal setara dengan 85 gram emas (Nurhayati dan Wasilah, 2014: 298-299).

Hafidhuddin (2002: 99) membagi zakat perusahaan ke dalam tiga cakupan perusahaan. Pertama, perusahaan yang memproduksi produk tertentu. Jika dihubungkan dengan kewajiban zakat, maka produk yang dihasilkan oleh perusahaan ini harus halal dan dimiliki oleh orang-orang yang beragama Islam. Kedua, perusahaan yang beroperasi di bidang jasa. Ketiga, perusahaan yang beroperasi di bidang keuangan, seperti lembaga keuangan, baik bank maupun nonbank (asuransi, reksadana, money changer).

Meskipun masih terdapat perbedaan pendapat dari ulama tentang wajib tidaknya zakat perusahaan, memasukkan zakat perusahaan sebagai salah satu zakat mal dipandang akan memberikan maslahah. Bertambahnya zakat perusahaan sebagai bagian dari zakat mal akan meningkatkan potensi zakat dan memberi manfaat bagi umat Islam dan perkembangan Islam. Hal tersebut karena zakat memiliki beberapa manfaat tidak hanya bagi orang yang berzakat (muzakki) dan penerimanya (mustahik), namun juga bagi harta yang dikeluarkan zakatnya, maupun bagi masyarakat secara keseluruhan. Menurut Hafidhuddin (2002: 10), di antara manfaat dari zakat adalah: 1). Sebagai ungkapan rasa syukur atas nikmat yang telah diberikan Allah SWT; 2) Zakat berfungsi untuk menolong dan membantu sesama untuk keperluan hidup sehari-hari agar kebutuhan primernya terpenuhi; 3).Sebagai sumber dana bagi pendirian infrastruktur yang perlu dimiliki oleh umat Islam; dan 4). Zakat sebagai salah satu alat pembersih harta, karena sebagian dari harta kita terdapat hak orang lain.

\subsection{ISLAMIC CORPORATE SOCIAL RESPONSIBILITY}

Islamic Corporate Social Responsibility (ICSR) merupakan pengembangan dari konsep CSR yang berasal dari Barat. Kelahiran CSR dipicu oleh semakin meningkatnya eksternalitas dari perusahaan-perusahaan bisnis (Gray et al., 1996). Menurut Gray et al., perusahaan seharusnya bertanggung jawab atas semua akibat dari kegiatan operasinya, tidak hanya kepada stakeholder secara ekonomi, namun juga terhadap lingkungan sosial dan lingkungan alam. Meski konsep CSR tersebut berasal dari Barat, secara umum tidak ada aspek dalam CSR yang bertentangan dengan Islam (Wardiwiyono, 2017). Lebih lanjut, Wardiwiyono (2017) menyampaikan bahwa karena konsep 
pertanggungjawaban dalam Islam berbeda secara fundamental dengan konsep Barat, maka konsep CSR perlu dikembangkan menjadi ICSR agar lebih sesuai dengan Islam.

Wardiwiyono (2013) mendefinisikan ICSR sebagai pertanggungjawaban organisasi bisnis Islam dalam memenuhi dan melindung stakeholder dan komunitas di sekitarnya dengan cara memenuhi kebutuhan dasar karyawan, mempromosikan kehidupan lingkungan sosial yang damai dan harmonis, serta membantu menciptakan keseimbangan alam agar tercapai kesejahteraan stakeholder dan komunitas. Bank syariah sebagai bagian dari organisasi bisnis Islam juga perlu menerapkan ICSR sebagai bentuk pertanggungjawabannya, baik baik pertanggungjawaban kepada stakeholders dan komunitas maupun pertanggungjawaban kepada Allah SWT.

Zubairu et al (2011) juga menyebutkan bahwa bank syariah diharapkan mampu dalam melakukan kegiatan tanggung jawab sosial perusahaan dan melaporkan bukti yang akurat dalam laporan keuangan. Pentingnya penerapan ICSR oleh bank syariah juga relevan dengan Shari'a Enterprise Theory yang menyatakan bahwa setiap enterprise/perusahaan dalam Islam tidak hanya bertanggung jawab terhadah stakeholder perusahaan, manusia dan alam sekitar melainkan juga pertanggungjawaban kepada Allah SWT. (Triyuwono, 2007).

Meskipun termasuk konsep baru, telah terdapat beberapa standar yang bisa dijadikan sebagai rujukan dalam penerapan ICSR. Konsep Islamic Ethical Identity yang dikembangkan Haniffa dan Hudaib (2007) dapat dianggap sebagai cikal bakal konsep ICSR untuk bank syariah. Konsep tersebut banyak diadopsi oleh peneliti-peneiti lain setelahnya untuk mengembangkan standar atau benchmark bagi penerapan ICSR. Salah satu standar ICSR yang relatif komprehensif dan khusus dikembangkan untuk bank syariah adalah standar pelaporan ICSR yang dikembangkan oleh Belal et al (2015).

Standar pengungkapan ICSR dari Belal et.al (2015) terdiri 149 item yang terbagi menjadi 89 item universal dan 60 item khusus. Item universal bersifat umum dan dikembangkan dari konsep CSR dan sustainability reporting dari Organisasi untuk Kerjasama Ekonomi dan Pembangunan (OECD) dan Global Reporting Initiative (GRI). Item khusus dikembangkan berdasar konsep Islamic Ethical Identity (Haniffa dan Hudaib, 2007), konsep CSR menurut AAOIFI, konsep pertanggungjawaban dalam Islam tambahan dari Belal et al. Item khusus berkaitan dengan kepatuhan terhadap syariah Islam.

Lebih lanjut, Belal et al (2015) mengelompokkan seluruh item pengungkapan ICSR menjadi 16 kategori. Keenambelas kategori tersebut adalah tata kelola perusahaan, dewan pengawas syariah, komitmen islam, zakat, dana kebajikan (qardhul hasan), kesadaran syariah, pengungkapan IFSB untuk mempromosikan transparansi dan disiplin pasar, dewan direksi, manajemen, keterlibatan masyarakat, kegiatan amal, sponsor, pengaduan, etika, karyawan, lingkungan. 


\subsection{RERANGKA KONSEPTUAL DAN PENGEMBANGAN HIPOTESIS}

Hubungan antara kinerja BUS, zakat dan ICSR dapat dijelaskan berdasarkan teori yang sudah ada seperti shariah enterprise theory, teori legitimasi maupun teori stakeholder serta berdasarkan hasil dari riset empiris terdahulu. Dalam penelitian ini, hubungan ketiga variabel tersebut dapat ditampilkan dalam Gambar1. Penjelasan gambar tersebut disajikan dalam sub bab pengembangan masing-masing hipotesis.

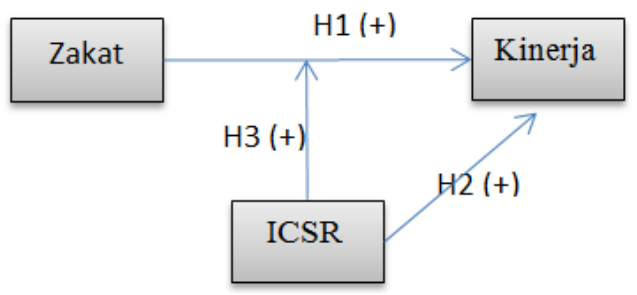

Gambar 1. Rerangka Konseptual dan Pengembangan Hipotesis

\subsubsection{Pengaruh Zakat Terhadap Kinerja BUS}

Zakat yang dibayarkan BUS dan dilaporkan dalam laporan rugi laba dapat memberikan indikasi bahwa BUS tersebut memiliki komitmen untuk membantu para pemilik dana mematuhi syariah Islam terutama dalam membayar zakat. Dari perspektif shariah enterprise theory, BUS yang membayar zakat menunjukkan bahwa BUS tersebut telah berusaha melaksanakan pertanggungjawabannya terhadap Allah swt. Menurut Islam, jika umat Islam mencoba mendekatkan diri kepada Allah melalui kepatuhan terhadap aturan-aturannya maka rahmat Allah yang dilimpahkan akan semakin besar (QS. Al A'raaf: 96 ). Dalam konteks BUS, BUS yang berusaha patuh terhadap syariah dengan membayar zakat atas keuntungan yang diperolehnya akan memperoleh keberkahan. Keberkahan tersebut akan dapat membawa ketenangan kepada para pimpinan dalam mengelola BUS, para karyawan dalam bekerja dan para investor dalam mendukung pendanaan BUS. Implikasinya, kinerja BUS yang diukur dari kemampuan menghasilkan keuntungan akan meningkat.

Selain itu, karena zakat yang dibayarkan akan didistribusikan kepada para mustahik yang menjadi bagian dari masyarakat luas, membayar zakat juga menunjukkan komitmen BUS terhadap lingkungan sosial. Dari perspektif teori legitimasi, ketika BUS menunjukkan komitmen yang baik kepada masyarakat, BUS akan memperoleh kepercayaan dan legitimasi dari masyarakat. Hal tersebut juga sesuai dengan fitroh dasar manusia yang apabila diberi kebaikan akan cenderung membalas dengan kebaikan. Dukungan dari masyarakat akan memudahkan BUS dalam menjalankan kegiatan bisnisnya. Akhirnya, kinerja pun akan dapat ditingkatkan.

Penjelasan dari perspektif dua teori tersebut didukung juga oleh hasilhasil riset terdahulu tentang pengaruh zakat terhadap kinerja BUS. Syurmita (2020), Ramadhani (2016), Sidik dan Reskino (2016) serta Amirah dan Teguh (2013) menemukan bahwa zakat berpengaruh positif terhadap kinerja bank syariah dalam menghasilkan keuntungan. Berdasarkan kajian teori dan 
kajian empiris yang telah disampaikan, hipotesis pertama yang diuji dalam penelitian ini adalah sebagai berikut:

H1. Zakat berpengaruh positif terhadap kinerja BUS.

\subsubsection{Pengaruh ICSR Terhadap Kinerja BUS}

Hubungan ICSR dengan kinerja BUS tidak jauh berbeda dengan hubungan antaran zakat dan kinerja BUS. Hal tersebut karena dalam praktik di lapangan maupun kajian akademis, zakat dianggap menjadi salah satu bentuk dari ICSR. Zakat adalah implementasi ICSR yang juga menjadi bagian dari ibadah umat Islam.

Merujuk dari konsep implementasi ICSR oleh entitas bisnis Islam yang dikembangkan oleh Wardiwiyono (2017), implementasi ICSR oleh BUS dapat dilihat dari bagaimana BUS berusaha memenuhi tangggung jawabnya kepada para karyawan, pemodal, pemilik rekening, nasabah pembiayaan dan stakeholder lainnya termasuk lingkungan alam dan lingkungan sosial. Implementasi ICSR menunjukkan komitmen BUS untuk menjaga kepentingan stakeholder dan apabila hal tersebut dipublikasikan kepada masyarakat luas, maka image BUS di mata stakeholder dan masyarakat akan meningkat. Dari perspektif teori stakeholder semakin baik komitmen BUS terhadap stakeholder, maka dukungan stakeholder terhadap BUS akan meningkat. Ditinjau dari teori legitimasi semakin baik image BUS di mata masyarakat, semakin mudah institusi tersebut mendapatkan dukungan. Oleh karena itu, semakin baik BUS menerapkan ICSR, makan dukungan dari stakeholder dan masyarakat akan meningkat. Dengan dukungan tersebut, kinerja BUS juga akan dapat ditingkatkan.

Dari perspektif shariah enterprise theory, implementasi dari ICSR oleh BUS juga dapat dilihat dari upaya bank dalam menjaga kehalalan produk perbankannya dan menjaga kepatuhan terhadap syariah Islam. Jika operasioal BUS semakin patuh terhadap ketentuan syariah, kepercayaan nasabah dan masyarakat Muslim terhadap BUS akan meningkat dan memudahkan BUS dalam melakukan operasional usahanya. Dengan demikian, kinerja BUS pun akan meningkat.

Penjelasan tentang hubungan ICSR dengan kinerja BUS dari perspektif teori tersebut relevan dengan beberapa penelitian terdahulu. Syurmita (2020), Nugraha (2019) dan Solekhah (2018) menemukan bahwa ICSR berpengaruh positif terhadap kinerja BUS.

Berdasarkan penjelasan tentang hubungan ICSR dan kinerja BUS baik berdasar teori legitimasi, teori stakeholder, shariah enterprise theory mapun hasil riset terdahulu, maka hipotesis kedua yang diuji dalam penelitian ini dinyatakan sebagai berikut:

H2. ICSR berpengaruh positif terhadap kinerja BUS.

\subsubsection{Peran ICSR Dalam Memoderasi Hubungan Zakat Dan Kinerja BUS}

Seperti telah dijelaskan sebelumnya, berdasarkan kajian teoritis dapat diduga bahwa zakat maupun ICSR memiliki pengaruh positif terhadap kinerja BUS. Artinya, semakin besar zakat perusahaan yang dibayarkan oleh BUS atau 
semakin baik implementasi ICSR oleh BUS, akan semakin besar pula kinerja BUS dalam menghasilkan keuntungan.

Berkaitan dengan hasil kajian empiris, riset terdahulu tentang pengaruh zakat terhadap kinerja menghasilkan temuan yang seragam dan sesuai hasil kajian teoritis. Namun demikian, untuk riset terdahulu yang berkaitan dengan pengaruh ICSR terhadap kinerja, hasil penelitian terdahulu memberikan dua kesimpulan yang berbeda. Sebagian penelitian terdahulu menemukan bahwa ICSR berpengaruh positif terhadap kinerja (Syurmita, 2020; Nugraha, 2019; Solekhah, 2018), namun sebagian penelitian yang lain tidak menemukan adanya pengaruh atau hubungan antara ICSR dengan kinerja (Indrayani dan Risna, 2018; Arifin dan Eke, 2016; serta Sidik dan Reskino, 2016). Perbedaan temuan tersebut membuka peluang untuk menguji ICSR tidak hanya sebagai variabel independen dalam mempengaruhi kinerja, namun juga sebagai variabel moderasi.

Secara teoritis, besarnya pengaruh zakat terhadap kinerja BUS akan berubah seiring dengan implementasi ICSR oleh BUS. Zakat sebagai bagian dari ICSR yang memiliki dasar hukum kuat dalam Islam akan memberikan dampak positif terhadap kinerja BUS. Namun demikian, karena sasaran penggunaan zakat hanya terbatas pada mustahik yang berhak, BUS perlu untuk memperhatikan anggota komunitas lainnya. ICSR dapat menjadi salah satu cara BUS dalam memperhatikan komunitas tersebut. Selain itu, karena zakat merupakan kewajiban religius maka membayar zakat bisa dipandang sebagai suatu bentuk kepatuhan. Berbeda dengan zakat, ICSR merupakan kesadaran yang bersifat sukarela. Ketika BUS menerapkan ICSR, maka BUS dapat dipandang sebagai entitas bisnis yang melakukan kebaikan bukan hanya karena tuntutan kewajiban saja. Stigson (2012) menyatakan bahwa CSR memberikan kesempatan kepada perusahaan-perusahaan untuk bertindak beyond compliance level.

Singkatnya, ICSR akan mampu memoderasi pengaruh zakat terhadap kinerja BUS. Membayar zakat menunjukkan bahwa BUS adalah entitas yang patuh terhadap syariah Islam, menerapkan ICSR menunjukkan bahwa BUS adalah entitas yang peduli terhadap lingkungan. Image yang dibentuk melalui kepatuhan terhadap syariah Islam dalam membayar zakat akan dipengaruhi juga oleh image kedermawanan melalui ICSR yang bersifat sukarela. Oleh karena itu, hipotesis ketiga yang diuji dalam penelitian ini dinyatakan sebagai berikut: H3. ICSR memoderasi pengaruh zakat terhadap kinerja BUS.

\section{METODE PENELITIAN}

Penelitian ini merupakan crosssectional study dengan data sekunder yang diperoleh dari laporan tahunan bank umum syariah di Indonesia. Data tersebut dikumpulkan dengan teknik dokumentasi dari berasa dari data tahun 2012 sampai 2017. Sampel penelitian diambil dengan menggunakan purposive sampling. Kriteria pengambilan sampel adalah sebagai berikut: Pertama, BUS yang terdaftar di Otoritas Jasa Keuangan dari tahun 2012- 
2017; Kedua, BUS yang mempublikasikan laporan tahunannya secara lengkap; Ketiga, BUS yang menerbitkan Laporan Sumber dan Penggunaan Dana Zakat. Berdasarkan kriteria tersebut, sampel akhir dari penelitian ini berjumlah 30 data observasi yang berasal dari 5 BUS selama 6 periode. Kelima BUS tersebut adalah Bank Muamalat, Bank Syariah Mandiri, BNI Syariah, BRI Syariah dan Bank Mega Syariah. Proses seleksi sampel akhir penelitian ditampilkan dalam tabel berikut.

Tabel.1 Proses seleksi sampel penelitian

\begin{tabular}{lc}
\hline $\begin{array}{l}\text { BUS yang terdaftar di OJK dari tahun 2012-2017 secara berturut- } \\
\text { turut }\end{array}$ & 13 \\
\hline BUS yang tidak mempublikasikan laporan tahunan & $(0)$ \\
\hline $\begin{array}{l}\text { BUS yang tidak menerbitkan Laporan Sumber dan Penggunaan Dana } \\
\text { Zakat }\end{array}$ & $(8)$ \\
\hline BUS yang menjadi sampel (13-8) & 5 \\
\hline Sampe akhir data observasi selama 6 tahun $(6 \times 5)$ & 30 \\
\hline
\end{tabular}

Sesuai dengan rumusan masalah dan hipotesis yang diajukan, penelitian ini melibatkan tiga variabel penelitian. Ketiga variabel tersebut adalah kinerja keuangan BUS, zakat, dan ICSR yang masing-masing mewakili variabel dependen, variabel independen dan variabel moderasi. Variabel kinerja keuangan BUS diukur dengan menggunakan Return on Asset (ROA), sedangkan variabel zakat diukur dengan menggunakan besarnya zakat perusahaan yang dilaporkan dalam Laporan Sumber dan Penggunaan Dana Zakat. Berkaitan dengan variabel ICSR, variabel ini diukur dengan indeks pengungkapan ICSR (ICSRD). Rumus ICSRD dituliskan sebagai berikut:

$$
I C S R D=\frac{\text { Jumlah skor yang diungkapkan }}{149} \times 100 \%
$$

Untuk mengukur jumlah skor yang diungkapkan, Peneliti melakukan content analysis dengan laporan tahunan BUS sebagai unit analisis. Konteks analisis yang dijadikan benchmark dalam proses content analysis adalah instrumen pengungkapan ICSR yang dikembangkan oleh Belal et al (2015). Karena instrumen Belal et al (2015) terdiri dari 149 item, maka angka tersebut dijadikan sebagai penyebut dalam rumus indeks pengungkapan ICSR. Angka 149 menunjukkan jumlah skor pengungkapan maksimal. Proses content analysis untuk menghitung jumlah skor yang diungkapkan dilakukan dengan memberikan angka 1 untuk item yang diungkapkan dalam laporan tahunan BUS dan angka 0 untuk item yang tidak diungkapkan.

Berkaitan dengan alat analisis, pada dasarnya terdapat dua prosedur yang dapat dipakai untuk menguji pengaruh variabel pemoderasi yaitu dengan subgroup analysis dan moderated regression analysis (MRA). Namun demikian, karena sampel data observasi dalam penelitian ini hanya berjumlah 30, subgroup analysis yang biasa dianalisis dengan Ramsey test tidak bisa dilakukan. Subgroup analysis dilakukan dengan mempartisi sampel data menjadi dua kelompok dengan menggunakan median data variabel 
moderasi sebagai pisah batasnya. Kedua kelompok sampel tersebut adalah kelompok sampel dengan data variabel moderasi di bawah nilai median dan kelompok sampel dengan data variabel moderasi di atas nilai median variabel moderasi. Selanjutnya, regresi sederhana dilakukan untuk masingmasing kelompok sampel dengan meregresikan variabel independen terhadap variabel dependen. Signifikansi perubahan nilai $\mathrm{R}^{2}$ dari kedua kedua regresi sederhana tersebut diuji dengan Ramsey test. Karena sampel data observasi dalam penelitian ini hanya 30, mempartisi sampel menjadi dua akan menjadikan jumlah sampel menjadi kecil. Akibatnya, regresi sederhana tidak dapat dilakukan.

Mempertimbangkan jumlah sampel data yang hanya 30, analisis yang digunakan untuk menjawab rumusan masalah penelitian ini hanya menggunakan MRA. Gujarati (2003) menyatakan bahwa untuk melakukan MRA perlu dikembangkan tiga model regresi. Oleh karena itu, Peneliti mengembangkan tiga model persamaan regresi untuk penelitian ini. Ketiga persamaan tersebut adalah sebagai berikut:

$$
\begin{aligned}
& \mathrm{ROA}=\alpha+\beta_{1} \mathrm{Zkt}+\mathrm{e} \\
& \mathrm{ROA}=\alpha+\beta_{1} \mathrm{Zkt}+\beta_{2} \mathrm{ICSRD}+\mathrm{e} \\
& \mathrm{ROA}=\alpha+\beta_{1} \mathrm{Zkt}+\beta_{2} \mathrm{ICSR}+\beta_{3} \mathrm{Zkt} * \mathrm{ICSRD}+\mathrm{e}
\end{aligned}
$$

Selain menggunakan MRA sebagai alat analisis utama, Peneliti juga menggunakan Statistik Deskriptif untuk memberikan gambaran tentang kinerja BUS, zakat yang dilaporkan dalam Laporan Sumber dan Penggunaan Dana Zakat serta ICSR yang diungkapkan BUS dalam laporan tahunan selama periode penelitian. Peneliti juga melakukan uji asumsi klasik yang mendasari penggunaan analisis regresi untuk memastikan bahwa asumsiasumsi tersebut terpenuhi untuk setiap model regresi.

\section{HASIL DAN PEMBAHASAN}

Hasil analisis statistik deskriptif digunakan untuk memberikan gambaran tentang kinerja BUS, pembayaran zakat perusahaan dan praktik ICSR yang dilakukan oleh kelima BUS dari tahun 2012 sampai dengan 2019. Hasil analisis tersebut disajikan dalam Tabel 2 berikut.

Tabel 2. Hasil Statistik Deskriptif

\begin{tabular}{lrrrrr}
\hline & $\mathrm{n}$ & \multicolumn{1}{c}{ Min } & \multicolumn{1}{c}{ Maks } & Rata-rata & $\begin{array}{r}\text { Deviasi } \\
\text { Standar }\end{array}$ \\
\hline ROA (\%) & 30 & 0,08 & 3,81 & 1,16 & 0,86 \\
\hline $\begin{array}{l}\text { ZAKAT } \\
\text { jutaan Rp) }\end{array}$ & 30 & 428,90 & $28.131,60$ & $7.169,03$ & $6.059,00$ \\
\hline ICSRD (\%) & 30 & 52,35 & 68,46 & 62,13 & 3,76 \\
\hline
\end{tabular}


Tabel tersebut menunjukkan bahwa nilai rata-rata ROA BUS selama periode pengamatan adalah 1,16\%. Merujuk Surat Edaran BI no 13 tahun 2011 tentang Penilaian Tingkat Kesehatan Bank Umum, angka tersebut menunjukkan bahwa secara rata-rata BUS yang menjadi sampel dalam penelitian ini berada dalam kondisi cukup sehat.

Berkaitan dengan zakat yang dilaporkan dalam Laporan Sumber dan Penggunaan Dana Zakat, secara rata-rata besarnya zakat perusahaan yang dibayarkan BUS yang menjadi sampel dalam penelitian ini selama 6 tahun periode pengamatan adalah sebesar 7,17 milyar rupiah. Angka tersebut menunjukkan rata-rata realisasi zakat perusahaan BUS selama tahun 20122017.

Tabel 2 juga menunjukkan bahwa secara rata-rata indeks pengungkapan ICSR di laporan tahunan BUS yang menjadi sampel dalam penelitian ini adalah $62 \%$. Artinya, $62 \%$ dari total item pengungkapan yang seharusnya diungkapkan menurut Belal et al (2015) telah diungkapkan oleh 5 BUS yang menjadi sampel dalam penelitian ini. Artinya, 92 item dari 149 item tentang pertanggungjawab entitas bisnis Islam telah diungkapkan oleh BUS di Indonesia. Angka ini tergolong tinggi jika dibandingkan dengan ratarata indeks pengungkapan ICSR yang dilaporkan oleh riset-riset terdahulu sebesar 34\% (Wardiwiyono, 2017). Bahkan, nilai terendah dari indeks pengungungkapan ICSR oleh 5 BUS sampel penelitian ini masih termasuk kategori tinggi (52,35\%).

Selanjutnya, sebelum melakukan analisis MRA, Peneliti melakukan uji asumsi klasik terhadap ketiga model regresi yang dirumuskan sebelumnya. Uji asumsi klasik tersebut meliputi beberapa uji sebagai berikut. Uji asumsi klasik yang pertama adalah uji normalitas. Uji ini dilakukan memastikan bahwa residual data dari masing-masing model regresi terdistribusi secara normal. Dengan menguji data residual dari masingmasing persamaan regresi, Peneliti menemukan bahwa signifikansi hasil Uji Kolmogorov Smirnov untuk masing-masing model regresi menunjukkan nilai di atas 5\%. Artinya, asumsi normalitas untuk ketiga model regresi telah terpenuhi.

Uji asumsi klasik yang kedua adalah uji heteroskedasitas yang ditujukan untuk memastikan tidak terjadinya heteroskedasitas (ketidaksamaan varian dari satu pengamatan ke pengamatan yang lain). Pengujian dilakukan dengan uji Glejser yaitu dengan meregresikan variabel independen dari setiap persamaan regresi terhadap nilai absolute dari data residual. Pengujian yang dilakukan sebanyak tiga kali menunjukkan bahwa nilai signifikasi $F$ dari persamaan regresi dalam uji Glejser menunjukkan angka di atas 5\%. Artinya, tidak ada masalah heteroskedastisitas dalam ketiga persamaan regresi dalam penelitian ini.

Ketiga, uji autokorelasi. Uji ini dilakukan untuk menguji apakah ketiga model regresi memiliki korelasi antara kesalahan pengganggu pada periode pengamatan dengan kesalahan pengganggu pada periode sebelumnya. Pengujian dilakukan dengan Durbin Watson Test yang hasil ujinya menunjukkan bahwa nilai Durbin Watson untuk masing-masing model 
berada di antara nilai durbin watson upper dan nilsi 4 dikurangi durbin watson upper ( $\mathrm{du}<\mathrm{d}<4-\mathrm{du}$ ). Merujuk pada kriteria pengujian autokorelasi dengan Durbin Watson Test yang dinyatakan oleh (Ghazali, 2018), maka dapat disimpulkan bahwa ketiga model regresi tidak mengalami masalah autokorelasi.

Uji asumsi klasik yang terakhir adalah uji multikolinearitas. Uji ini ditujukan untuk mengetahui apakah terdapat korelasi di antara variabel independen. Uji multikolinearitas hanya dilakukan pada model 2 dan model 3. Pada model 2, nilai VIF untuk kedua variabel zakat dan ICSR kurang dari 10. Oleh karena itu dapat disimpulkan bahwa tidak ada masalah dengan multikolinearitas pada model 2. Namun demikian, nilai VIF untuk variabel independen pada model 3 menunjukkan angka lebih dari 10. Hal ini menunjukkan terjadinya multikolinearitas pada model 3. Hal tersebut dapat dikatakan wajar karena model ketiga menggunakan ICSR sebagai variabel moderasi.

Selanjutnya, karena uji asumsi klasik hampir semua terpenuhi, maka ringkasan hasil analisis MRA disajikan dalam Tabel 3 berikut ini.

Tabel 3. Ringkasan Hasil Multiple Regression Analysis

\begin{tabular}{|c|c|c|c|}
\hline Model & Persamaan & F test & $\mathrm{R}^{2}$ \\
\hline \multirow[t]{3}{*}{1} & $\mathrm{Y}=\beta_{1} \mathrm{Zkt}+\mathrm{e}$ & & \\
\hline & $\mathrm{Y}=3,519 \mathrm{Zkt}+\mathrm{e}$ & 1,817 & $\mathrm{R}^{2}$ Old \\
\hline & t sig. $(0,188)$ & Sig: 0,188 & 0,027 \\
\hline \multirow[t]{3}{*}{2} & $\mathrm{Y}=\beta_{1} \mathrm{Zkt}+\beta_{2} \mathrm{ICSR}+\mathrm{e}$ & & \\
\hline & $\mathrm{Y}=4,655 \mathrm{Zkt}-13,141 \mathrm{ICSR}+\mathrm{e}$ & 8,330 & $\mathrm{R}^{2} \mathrm{New}$ \\
\hline & t sig. $(0,042)(0,001)$ & Sig. 0,002 & 0,336 \\
\hline \multirow[t]{3}{*}{3} & $\mathrm{Y}=\beta_{1} \mathrm{Zkt}+\beta_{2} \mathrm{ICSR}+\beta_{3} \mathrm{Zkt} * \mathrm{ICSR}+\mathrm{e}$ & & $\mathrm{R}^{2} \mathrm{New}$ \\
\hline & $\begin{array}{l}\mathrm{Y}=1,433 \mathrm{Zkt}-3,163 \mathrm{ICSR}-2,212 \\
\mathrm{Zkt} * \mathrm{ICSR}+\mathrm{e}\end{array}$ & 8,609 & \\
\hline & t sig. $(0,017)(0,547)(0,021)$ & Sig. 0,000 & 0,440 \\
\hline
\end{tabular}

Pada model regresi pertama, Peneliti tidak mampu membuktikan H1 atau tidak mampu menemukan signifikansi pengaruh zakat terhadap kinerja keuangan BUS. Hal tersebut karena nilai signifikansi dari hasil t-test lebih besar dari 5\% (0,188). Hasil ini juga dikonfirmasi dengan nilai $\mathrm{R}^{2}$ yang rendah yaitu 0,027. Artinya, hanya 2,7\% variasi kinerja keuangan BUS yang mampu dijelaskan oleh zakat perusahaan. Sisanya sebesar 97,3\% dijelaskan oleh variabel lain yang tidak dimasukkan dalam model.

Untuk model regresi kedua, hasil analisis regresi menunjukkan bahwa nilai signifikansi hasil uji t untuk variabel zakat dan ICSR masing-masing adalah 0,042 dan 0,001 (kurang dari 5\%) dengan koefisien beta bertanda masing-masing positif dan negatif. Berdasar kedua hal tersebut dapat disimpulkan bahwa $\mathrm{H} 1$ diterima, sedangkan $\mathrm{H} 2$ ditolak. $\mathrm{H} 1$ diterima memberikan arti bahwa zakat berpengaruh positif terhadap kinerja BUS. Temuan tersebut relevan dengan hasil riset terdahulu yang dilakukan oleh 
Syurmita (2020), Ramadhani (2016), Sidik dan Reskino (2016) serta Amirah dan Teguh (2013).

Berkaitan dengan hipotesis kedua, hasil analisis regresi model (2) menyimpulkan bahwa $\mathrm{H} 2$ tidak dapat diterima. Hal tersebut karena hasil regresi tersebut menunjukkan bahwa ICSR berpengaruh negatif terhadap kinerja sedangkan dalam hipotesis kedua Peneliti menduga bahwa ICSR berpengaruh positif terhadap kinerja. Akan tetapi, berdasar nilai signifikansi uji $\mathrm{t}$ untuk variabel ICSR dan nilai koefisien betanya, Peneliti dapat mengambil kesimpulan bahwa ICSR berpengaruh negatif terhadap kinerja BUS. Temuan ini bertentangan dengan hasil yang dilaporkan oleh Syurmita (2020), Nugraha (2019) dan Solekhah (2018). Hal tersebut menunjukkan bahwa semakin banyak ICSR yang diungkapkan, maka semakin berkurang kinerja BUS yang diukur dengan ROA. Temuan tersebut bisa saja terjadi karena data ROA yang dipakai dalam penelitian ini berasal dari periode yang sama dengan data ICSR.

Dalam jangka pendek, implementasi ICSR oleh sebuah perusahaan sebenarnya merupakan biaya yang dibebankan oleh perusahaan. Semakin banyak ICSR yang dilakukan oleh bank berarti semakin besar juga biaya yang dikeluarkan. Dampak lebih lanjut, ketika biaya yang dibebankan perusahaan semakin meningkat maka keuntungan pada periode tersebut akan mengalami penurunan sehingga ROA menjadi lebih kecil. Hal tersebut sejalan dengan resources based theory, semakin tinggi alokasi aset untuk ICSR maka akan menurunkan peluang bagi aset tersebut dalam membantu meningkatkan keuntungan perusahaan dalam jangka pendek.

Temuan ini juga memberikan indikasi bahwa teori legitimasi dan teori stakeholder yang dijadikan dasar dalam pengembangan hipotesis penelitian yang kedua hanya cocok untuk digunakan untuk menjelaskan pengaruh ICSR terhadap kinerja BUS dalam jangka yang lebih panjang. Implementasi ICSR dalam jangka panjang akan dapat meningkatkan image perusahaan di mata masyarakat/stakeholder sehingga akan meningkatkan peluang perusahaan untuk berkinerja lebih baik. Namun demikian, dalam jangka pendek, implementasi ICSR merupakan biaya yang akan mengurangi keuntungan perusahaan. Akibatnya, ICSR dalam jangka pendek akan menurunkan kinerja perusahaan dalam menghasilkan laba.

Untuk model regresi ketiga, Tabel 3 menunjukkan bahwa interaksi antara variabel zakat dan ICSR memiliki nilai signifikansi t sebesar 0,021 $(<5 \%)$. Artinya, variabel ICSR mampu memoderasi pengaruh zakat terhadap kinerja keuangan. Lebih lanjut, merujuk pada Sugiono (2004), karena $\beta_{2}$ ICSR pada persamaan model regresi 2 memiliki nilai yang signifikan dan $\beta_{3}$ Z*ICSR pada persamaan model regresi 3 juga signifikan, maka variabel ICSR dapat dikelompokkan ke dalam variabel moderasi berjenis quasi moderator.

Berkaitan dengan nilai koefisien determinasi $\left(\mathrm{R}^{2}\right)$, nilai $\mathrm{R}^{2}$ untuk model (2) dan (3) masing-masing adalah 33,6\% dan 44\%. Nilai tersebut menunjukkan bahwa model (3) memiliki nilai prediksi yang lebih baik dibandingkan dengan model (2). Hal tersebut dapat mengindikasikan bahwa 
penambahan ICSR sebagai variabel moderasi mampu meningkatkan kemampuan model regresi dalam menjelaskan variasi kinerja BUS yang diukur dengan ROA.

\section{SIMPULAN}

Berdasarkan hasil analisis data yang berasal dari 5 BUS selama tahun 20122017 penelitian ini telah berhasil menjawab pertanyaan penelitian yang telah dituliskan sebagai rumusan masalah pada bagian Pendahuluan. Pertanyaan penelitian dan jawaban yang telah diperoleh dapat disajikan sebagai berikut. Pertama, rumusan masalah pertama menanyakan apakah zakat berpengaruh terhadap kinerja BUS. Hasil penelitian ini memberikan bukti empiris bahwa zakat berpengaruh positif terhadap kinerja BUS. Kedua, rumusan masalah kedua menanyakan apakah ICSR berpengaruh terhadap kinerja BUS. Berdasar hasil analisis, penelitian ini menemukan bahwa ICSR berpengaruh negatif terhadap kinerja BUS. Ketiga, rumusan masalah ketiga menanyakan apakah ICSR memoderasi pengaruh zakat terhadap kinerja BUS. Hasil analisis regresi dalam penelitian ini mengkonfirmasi bahwa ICSR mampu memoderasi pengaruh zakat terhadap kinerja BUS yang diukur dengan ROA.

Penelitian ini memiliki implikasi bagi pengembangan teori yang dapat dipakai untuk menjelaskan hubungan zakat, ICSR dan kinerja. Temuan dari penelitian ini mampu mendukung teori legitimasi dan shariah enterprise theory dalam menjelaskan pengaruh zakat terhadap kinerja. Untuk pengaruh ICSR terhadap kinerja, penelitian ini mengkonfirmasi penerapan resources based theory yang dapat dipakai untuk menjelaskan pengaruh ICSR terhadap kinerja BUS dalam jangka pendek. Dari segi praktis, penelitian ini dapat menjadi pertimbangan bagi BUS untuk melaksanakan pembayaran zakat perusahaan. Dengan ditemukannya pengaruh positif zakat terhadap kinerja, diharapkan BUS akan tertarik untuk membayar zakat perusahaannya. Lebih lanjut, diharapkan penerimaan zakat di Indonesia dapat ditingkatkan.

Meskipun penelitian ini telah dilakukan menurut kaidah dan metode ilmiah yang benar, namun Peneliti yang akan datang dapat melakukan penyempurnaan dalam beberapa hal. Pertama, sampel penelitian ini hanya terdiri dari 30 data observasi. Akibatnya, Peneliti tidak dapat melakukan subgroup analysis untuk mengkonfirmasi peran variabel moderasi yang telah dibuktikan melalui MRA. Peneliti yang akan datang diharapkan dapat memperbesar sampel data observasi sehingga bisa melakukan subgroup analysis. Kedua, penelitian ini tidak mampu mendukung hipotesis kedua yang diajukan Peneliti sehingga memberikan indikasi bahwa penggunaan teori legitimasi dan teori stakeholder dalam menjelaskan hubungan ICSR dan kinerja bisa jadi lebih cocok untuk jangka panjang. Oleh karena itu, Peneliti yang akan datang sebaiknya tidak menggunakan data kinerja dari tahun yang sama dengan tahun data ICSR. Artinya, kinerja bisa diukur dengan data tahun berikutnya $(\mathrm{t}+1)$. 


\section{DAFTAR PUSTAKA}

Ali, M. (1988). Sistem ekonomi islam zakat dan wakaf (Edisi 1), Jakarta: Penerbit Universitas Indonesia (UI-Press).

Amirah \& Raharjo, T, B. (2013). Pengaruh alokasi dana zakat terhadap kinerja keuangan perbankan syariah, 73-81.

Arifin, J., \& Wardani, E. (2016). Islamic corporate social responsibility disclosure, reputasi, dan kinerja keuangan: studi pada bank syariah di Indonesia. Jurnal Akuntansi \& Auditing Indonesia, 20(01), 37-46.

Belal, A., Abdelsalam, O., Nizamee, S. (2015). Ethical reporting in Islamic Bank Bangladesh limited (1983-2010). Journal of business ethics, 139.

Firmansyah, I., \& Rusydiana, A. (2013). Pengaruh profitabilitas terhadap pengeluaran zakat pada Bank Umum Syariah di Indonesia dengan ukuran perusahaan sebagai variabel moderasi. Jurnal Liquidity, 2(2), 110-116.

Ghozali, I. (2018). Aplikasi analisis multivariate dengan proram IBM SPSS 25. Semarang: Universitas Diponegoro.

Gujarati, N., Damodar. (2003). Basic econometrics international edition (Edisi 4). New York: Mc GRAW-HILL.

Hafidhuddin, D. (2002). Zakat dalam perekonomian modern (Edisi 1). Jakarta: Gema Insani.

Indrayani dan Risna (2018) Pengaruh Islamic Corporate Social Responsibility (ICSR) dan Shariah Governance terhadap Kinerja Perusahaan (Studi Empiris Bank Umum Syariah yang terdaftar di Bursa Efek Indonesia tahun 2012-2016), Jurnal Akuntansi, Keuangan dan Perpajakan Indonesia, 6(01).

Kurniawan, A., \& Suliyanto. (2013). Zakat sebagai aspek tabaru dan pengungkapan islamic social reporting terhadap kinerja keuangan: sebuah agenda penelitian. Jurnal Akuntansi, 51-68

Lestari, A. (2018). Analisis pengaruh ICSR (Islamic Corporate Social Responsibility) dan zakat terhadap reputasi dan profitabilitas perusahaan: studi empiris pada bank syariah di Indonesia. Dikutip pada https://dspace.uii.ac.id/handle/123456789/7633. diakses pada tanggal 08 Januari 2019, jam 10.00.

Muhammad (2005). Konstruksi mudharabah dalam bisnis syariah. Yogyakarta: BPFE-Yogyakarta.

Nugraha, I.S. (2019) Pengaruh Islamic Corporate Social Responsibility (ICSR) dan Islamic Corporate Governance (ICG) terhadap Kinerja Keuangan Bank Umum Syariah Menggunakan Islamicity Performance 
Index (Survei pada Bank Umum Syairah yang terdaftar di OJK). Sarjana Tehsis, Universitas Siliwangi.

Nurhayati, Sri dan Wasilah. (2014). Akuntansi syariah di Indonesia (Edisi 4). Jakarta: Salemba Empat.

Republika.co.id (2019). Kemenag: Potensi zakat nasional capai Rp 217 Triliun. Dikutip pada https://www.republika.co.id/berita/duniaislam/islam-nusantara/18/02/23/p4m1gs409-kemenag-potensi-zakatnasional-capai-rp-217-triliun. diakses pada tanggal 07 November 2019, jam 10:50.

Republika.co.id (2019). BNI Syariah dorong dana zakat di perbankan syariah. Dikutip pada https://www.republika.co.id/berita/ekonomi/syariahekonomi/18/03/20/p5w6a0415-bni-syariah-dorong-dana-zakat-diperbankan-syariah. diakses pada tanggal 07 November 2019, jam 13.00 .

Rhamadhani, R. (2016). Pengaruh zakat terhadap kinerja perusahaan. Hunafa: Jurnal Studia Islamika, 13(2), 344-361.

Sawitri, D, R., Jauanda, A., \& Jati, A, W. (2017). Analisis pengungkapan corporate social responsibility perbankan syariah Indonesia berdasarkan Islamic Social Reportng Index. Jurnal Reviu Akuntansi \& Keuangan, 7(1), 983-991.

Sharma, Subahash. (1981). Identification and Analysis of Moderator Variables, Journal of Marketing Research Vol. XVIII.

Sidik, I., \& Reskino. (2016). Zakat and Islamic corporate social responsibility: Do these effect the performance of sharia banks?. Journal of economics and business, 1(2), 161-184.

Sholekhah, Eka Nikmatush. (2018) Pengaruh pengungkapan Islamic corporate social responsibility terhadap kinerja keuangan dengan good corporate Governance sebagai variabel moderating: Studi empiris pada Bank Syariah di Indonesia. Undergraduate thesis, Universitas Islam Negeri Maulana Malik Ibrahim.

Sugiyono. (2004). Metode penelitian. Bandung: Alfabeta.

Wardiwiyono, S. (2013). Toward Sustainable Success trough Corporate Social Responsibilites: An Islamic Perspective, International Journal of Green Economics, 7(1), page 86-101.

Wardiwiyono, S. (2017). Islamic Corporate Social Responsibility Disclosure in Organization of Cooperation Countries. Unpublished PhD thesis, University of Huddersfield. 
